\title{
Osmotic adjustment in Brevibacterium ammoniagenes: pipecolic acid accumulation at elevated osmolalities
}

\author{
Gwenola Gouesbet, ${ }^{1}$ Carlos Blanco, ${ }^{1}$ JaCk Hamelin ${ }^{2}$ and ThÉophile Bernard ${ }^{1 *}$ \\ ${ }^{1}$ Laboratoire de Génétique et Physiologie Microbiennes (CNRS URA 256) and ${ }^{2}$ Groupe de Recherche de Physico-chimie \\ structurale (CNRS URA 704), Université de Rennes I, Campus de Beaulieu, Av. du Général Leclerc, 35042 Rennes \\ Cedex, France
}

(Received 21 October 1991; revised 22 January 1992; accepted 7 February 1992)

\begin{abstract}
Brevibacterium ammoniagenes ATCC 6872 was grown aerobically in minimal defined glucose media of different osmolalities induced either by $\mathrm{NaCl}$, other eletrolytes or non-electrolytes. Growth rate was slightly affected by elevation of medium osmolality up to $1 \mathrm{M}-\mathrm{NaCl}$, but severely decreased at $1.5 \mathrm{M}$; however even at $2 \mathrm{M}-\mathrm{NaCl}$, slow growth still occurred. Glycine betaine (or its precursor choline) did not stimulate growth in high osmotic media, although it accumulated intracellularly and was not metabolized. An organic solute which increased substantially in concentration during osmotic treatment with various osmolytes, was isolated and identified as pipecolic acid. No accumulation of this imino acid was observed when the medium concentration was raised by adding the permeant glycerol or when the culture medium was supplemented with glycine betaine $(1 \mathrm{mM})$. While this non-proteic cyclic amino acid may play an important role in bacterial adaptation to environmental stress, it did not accumulate to a high level. Preliminary data suggest that the biosynthesis of pipecolic acid from lysine is strongly regulated by external osmolality.
\end{abstract}

\section{Introduction}

The ability to adapt, within limits, to changes in the osmotic strength of the environment is a property of most living cells. Many species of bacteria respond to elevated medium osmotic pressure by accumulating inorganic ions and low-molecular-mass organic solutes, such as amino acids and their derivatives, or carbohydrates, to high intracellular concentrations (Brown, 1976; Yancey et al., 1982; Imhoff, 1986). The primary response to osmotic stress in bacteria is the accumulation of $\mathrm{K}^{+}$ ions (Christian \& Waltho, 1961; Epstein, 1986), with a concomitant increase in glutamate concentration (Measures, 1975; Tempest et al., 1970; Botsford, 1984; Hua et al., 1982; Makemson \& Hastings, 1979; Yap \& Lim, 1983). As a secondary response, the microorganism can take up large amounts of osmotically active solutes such as proline and betaines. Exogenous osmoprotectants such as proline, choline (converted into glycine betaine intracellularly) and betaines are taken up via osmotically regulated transport systems, stimulating or restoring the growth of stressed cells (Imhoff, 1986; Christian, 1955; Dunlap \& Csonka, 1985; Perroud \& Le

\footnotetext{
- Author for correspondence. Tel. 99286140.
}

Rudulier, 1985; Le Rudulier \& Bernard, 1986; Bernard et al., 1986).

Most studies on osmoregulation in the bacterial world have been confined to enterobacteria and other Gramnegative bacteria, with only a few reports on Grampositive bacteria (Hutkins et al., 1987; Whatmore et al., 1990). Despite the fact that coryneform bacteria are among the most useful organisms for the industrial production of amino acids and nucleotides and that the osmotic potential of the medium is an important factor for the production of metabolites, they have been little studied. To our knowledge, osmoprotection has only been investigated in Brevibacterium lactofermentum (Kawahara et al., 1989, 1990). This investigation demonstrated the relief of the effects of osmotic stress by endogenous proline and exogenously supplied glycine betaine.

In this paper, we report the ability of Brevibacterium ammoniagenes to sustain growth on media of high osmotic strength and the strategy developed by this bacterium to maintain osmotic balance. The effect of the well-known exogenous osmoprotectant glycine betaine was analysed, and a potential new osmoprotectant for bacteria was isolated and subsequently identified as pipecolic acid. 


\section{Methods}

Culture and growth conditions. Brevibacterium ammoniagenes ATCC 6872 was grown aerobically at $30^{\circ} \mathrm{C}$ with constant shaking (130 r.p.m.) on the defined M63 minimal medium (Miller, 1972) using glucose or lactate as carbon source. Minimal media of elevated osmotic strength were obtained by adding $\mathrm{NaCl}, \mathrm{KCl}$ or the non-electrolytes sucrose, sorbitol or glycerol at the concentrations indicated. The osmoprotectants glycine betaine and choline were added to a concentration of $1 \mathrm{~mm}$. The osmotic pressure of each medium was measured before use by freezing-point determination. An overnight exponential-phase culture on LB medium (Miller, 1972) was used as inoculum at a final concentration of $2 \%(\mathrm{v} / \mathrm{v})$.

Bacterial growth was monitored as $\mathrm{OD}_{570}$. The dry weight (DW) was estimated on washed cells, oven-dried at $80^{\circ} \mathrm{C}$ until constant weight. For physiological studies, cells in exponential growth phase were harvested by centrifugation, washed twice with an isotonic solution and maintained at $4^{\circ} \mathrm{C}$ until use.

Extraction of cellular solutes. The pellet of freshly washed cells was extracted at least twice in $80 \%(\mathrm{v} / \mathrm{v})$ ethanol under vigorous magnetic stirring at room temperature for $15 \mathrm{~min}$. After centrifugation, the combined supernatants were filtered and evaporated to dryness at $40^{\circ} \mathrm{C}$. The dried extract was dissolved in a minimum volume of distilled water and stored at $-20^{\circ} \mathrm{C}$ until analysis. This constituted the ethanol-soluble fraction (ESF); the extraction pellet, including the ethanol-insoluble cell components, was termed the EIF fraction.

Chromatographic analysis. ESF was used directly or after partial purification by passage through a cation-exchange column $(20 \mathrm{~cm} \times$ $1 \mathrm{~cm}$ ) of Bio-Rad AG50 $\times 8, \mathrm{H}^{+}$form. Amino acids were eluted with $2 \mathrm{M}-\mathrm{NH}_{4} \mathrm{OH}$; the solution was evaporated to dryness and the residue dissolved in $1 \mathrm{ml}$ distilled water. The eluted fraction was subjected to paper chromatography (Whatman 1 and $3 \mathrm{MM}$ ) or TLC (silica gel $60 \mathrm{~F}_{254}$, Merck, $0.2 \mathrm{~mm}$ thickness), high-voltage electrophoresis (Whatman 3MM paper, $3 \%$ formic acid, electric field value of $40 \mathrm{~V}$ $\mathrm{cm}^{-1}$ ), and HPLC.

Paper chromatography and TLC were run in two different solvents: $n$-butanol/acetic acid/water $(12: 3: 5$, by vol.) and aqueous phenol $(20 \%, \mathrm{v} / \mathrm{v}$ water $) / \mathrm{ethanol}(1: 1, \mathrm{v} / \mathrm{v})$. For amino acid quantification, HPLC analysis was done using the Beckman Gold System equipped with a reversed-phase ultrasphere ODS $5 \mu \mathrm{m}$ column $(4.6 \mathrm{~mm} \times$ $25 \mathrm{~cm}$ ). The amino acids were derivatized prior to injection using 4dimethylaminoazobenzene-4'-sulphonyl chloride (Dabsyl chloride, Fluka) and detected at $436 \mathrm{~nm}$ (Chang et al., 1983). An elution gradient starting with a mixture of $12 \mathrm{~mm}$-sodium citrate $(83 \%)$ /acetonitrile $(17 \%)$ (both $v / v)$ and ending at 80 min with $100 \%$ acetonitrile was programmed. Formamide $(4 \%, v / v)$ was added to both elution solvents. The flow rate was set at $1.4 \mathrm{ml} \mathrm{min}^{-1}$ and the column temperature was maintained at $35^{\circ} \mathrm{C}$. 3-Nitro-L-tyrosine (Fluka) was added as the internal standard. All experiments were repeated with less than $5 \%$ error.

Proline was detected by paper chromatography and HPLC analysis; alternatively it was assayed as described by Troll \& Lindsley (1955).

Pipecolic acid purification. Samples for spectral analysis were prepared from cells grown for $36 \mathrm{~h}$ in 11 of M63 medium supplemented with $1 \mathrm{M}-\mathrm{NaCl}$. After centrifugation, the cell pellet was suspended in $80 \%(v / v)$ ethanol and extracted three times. Cell debris was removed by centrifugation $(3500 \mathrm{~g}, 10 \mathrm{~min})$ and the resulting ESF was submitted to preparative chromatography on Whatman $3 \mathrm{MM}$ paper using aqueous phenol/ethanol $(1: 1, \mathrm{v} / \mathrm{v})$ as solvent. After drying at $40^{\circ} \mathrm{C}$, the bands corresponding to the unknown compound were localized by spraying with ninhydrin ( $0.4 \%$ in $n$-butanol) while the unsprayed corresponding strips were cut off and eluted with $2 \mathrm{mM}-\mathrm{HCl}$. After evaporation to dryness, the samples were further purified by highvoltage paper electrophoresis $\left(1 \mathrm{~h}\right.$ at $\left.30 \mathrm{~V} \mathrm{~cm}^{-1}\right)$, eluted as before and lyophilized. The dry sample (at least $10 \mathrm{mg}$ ) was dissolved in $\mathrm{D}_{2} \mathrm{O}$ for ${ }^{13} \mathrm{C}$ and ${ }^{1} \mathrm{H}$ NMR analysis using a Bruker $\mathrm{AC}$ 300P spectrometer.

NMR spectroscopy and mass spectrometry. The natural abundance ${ }^{13} \mathrm{C}$ NMR spectra were recorded in the pulsed Fourier transform mode at an operational frequency of $75 \cdot 4 \mathrm{MHz}$.

The ${ }^{1} \mathrm{H}$ NMR spectra were recorded at $300 \mathrm{MHz}$. The solvent $\left(\mathrm{D}_{2} \mathrm{O}\right)$ provided the signal for the NMR field lock. Chemical shifts were expressed in parts per million (p.p.m.) downfield from sodium 3(trimethylsilyl) propane sulphonate (DSS) which was added as an internal reference. The multiplicity of the signals were given as singlets $(s)$, doublets $(d)$, triplets $(t)$, quadruplets $(q)$ and multiplets $(m)$.

Mass spectrometry was performed using a Varian Mat 311 spectrometer with the following parameters : electron energy, $70 \mathrm{eV}$; accelerating voltage, $3000 \mathrm{~V}$; temperature of direct-insertion probe, $180^{\circ} \mathrm{C}$.

Radiolabelling assays. To determine the effect of salt on lysine uptake and metabolism, L-[U-14C]lysine monohydrochloride $(11 \cdot 1 \mathrm{GBq}$ $\mathrm{mmol}^{-1}$; Amersham, France) was supplied to a cell suspension grown to mid-exponential phase on minimal medium. Each assay, with or without $\mathrm{NaCl}$, contained, in a total volume of $0.5 \mathrm{ml}$, labelled lysine at a final concentration of $360 \mathrm{nM}\left(4 \times 10^{5}\right.$ d.p.m.). The mixture was incubated with shaking at $30^{\circ} \mathrm{C}$ for $2 \mathrm{~h}$ and the soluble compounds were extracted with $80 \%(\mathrm{v} / \mathrm{v})$ ethanol as described above. Respired $\mathrm{CO}_{2}$ was trapped on a strip of filter paper $(1 \times 3 \mathrm{~cm})$ moistened with $0.2 \mathrm{ml}$ of $6 \mathrm{M}-\mathrm{KOH}$. Subsamples of ESF, and the whole EIF and $\mathrm{CO}_{2}$, were transferred into counting vials with BCS liquid scintillant (Amersham, France). The radioactivity of each fraction was determined using a Packard Tri-Carb spectrometer. A subsample of the insoluble fraction was treated with $6 \mathrm{M}-\mathrm{HCl}$ at $105^{\circ} \mathrm{C}$ for $20 \mathrm{~h}$ in sealed vials and chromatographed in order to determine the nature of labelled compounds incorporated into hydrolysable macromolecular components.

Transport assays. $[1,2-14 \mathrm{C}] \mathrm{Glycine}$ betaine was prepared from $[1,2-$ ${ }^{14} \mathrm{C}$ choline $\left(1.6 \mathrm{GBq} \mathrm{mmol}^{-1}\right)$ as described by Ikuta et al. (1977). $\left[{ }^{14} \mathrm{C}\right]$ Choline was enzymically oxidized by choline oxidase from Alcaligenes sp. (Sigma). To isolate $\left[{ }^{14} \mathrm{C}\right]$ glycine betaine, the reaction mixture was subjected to high voltage electrophoresis at $40 \mathrm{~V} \mathrm{~cm}^{-1}$, with Whatman $3 \mathrm{MM}$ paper previously moistened in $3 \%(\mathrm{v} / \mathrm{v})$ formic acid (pH 2.0). The [ $\left.{ }^{14} \mathrm{C}\right]$ glycine betaine was thoroughly eluted with $10 \mathrm{mM}-\mathrm{HCl}$ which was then removed by rotary evaporation. The purity was checked by co-electrophoresis and co-chromatography with pure glycine betaine.

Cells used for transport assays were grown to an $\mathrm{OD}_{570}$ of 0.5 , harvested by centrifugation $(3500 \mathrm{~g}$ for $10 \mathrm{~min}$ ), washed twice with growth medium lacking carbon source and concentrated to $\mathrm{OD}_{570}=1$ in the same solution. Transport was initiated by adding $1 \mathrm{ml}$ of cell suspension to $25 \mu] \quad\left[{ }^{14} \mathrm{C}\right] g l y c i n e$ betaine or $\left[{ }^{14} \mathrm{C}\right]$ choline $\left(20 \times 10^{3}\right.$ d.p.m., $\left.0 \cdot 16 \mu \mathrm{M}\right)$. Samples $(0 \cdot 1-0 \cdot 2 \mathrm{ml})$ were taken at intervals and rapidly collected on $2.5 \mathrm{~cm}$ glass-fibre filters (Whatman type $\mathrm{GF} / \mathrm{F}$ ) and washed twice with a solution of the suspension medium. Dried filters were introduced into scintillation vials containing $6 \mathrm{ml}$ BCS. Radioactivities were determined in a Packard Tri-Carb spectrometer. In all experiments, the total concentration of glycine betaine or choline in the transport assays was adjusted so that no more than $20 \%$ of the substrate was taken up during the course of the experiment. When chloramphenicol was used, the inhibition of growth was verified by monitoring cell density, which did not increase within $1 \mathrm{~h}$ after addition of the antibiotic. All data presented are mean values of duplicates from at least three different experiments, and results agreed within less than $10 \%$ deviation. 


\section{Results}

\section{Effect of increased osmolality on bacterial growth}

To analyse the response to increased medium osmolality, Brevibacterium ammoniagenes was grown on minimal M63 medium with $\mathrm{NaCl}$ at different concentrations from 0-1.5 M. The osmotic pressures developed by these culture media were [osmol (kg water) ${ }^{-1}$ ]: $0 \cdot 26$ (no added $\mathrm{NaCl}) ; 1.12(0.5 \mathrm{M}-\mathrm{NaCl}) ; 2.20(1.0 \mathrm{M}-\mathrm{NaCl}) ;$ and 2.96 $(1.5 \mathrm{M}-\mathrm{NaCl})$.

Exposure to elevated osmotic strength reduced the growth rate from 0.20 generations $h^{-1}$ in minimal medium without added $\mathrm{NaCl}$, to 0.14 generations $\mathrm{h}^{-1}$ in $1 \mathrm{M}-\mathrm{NaCl}$ (Fig. 1). At salinities above $1 \mathrm{M}-\mathrm{NaCl}$, growth rate decreased sharply with only 0.04 generations $\mathrm{h}^{-1}$ in $1.5 \mathrm{M}-\mathrm{NaCl}$. At $2 \mathrm{M}-\mathrm{NaCl}$, only very slow growth occurred (data not shown). The culture absorbance at the stationary phase decreased from 0 to $0.5 \mathrm{M}-\mathrm{NaCl}$, but no significant change appeared from 0.5 to $1 \mathrm{M}$. In $1.5 \mathrm{M}$ $\mathrm{NaCl}$, the absorbance reached only $10 \%$ of that obtained with cells grown without $\mathrm{NaCl}$.

Due to probable changes in cell size during osmolality enhancement, leading to modification in light scattering and hence in absorbance (Koch, 1984), it seems preferable to define growth in terms of cell biomass. Dry weight was measured from bacterial suspensions grown at different salinities $(0,0.5,1.0$ and $1.5 \mathrm{M}-\mathrm{NaCl})$ and harvested at the termination of growth. Cell biomass showed a $57 \%$ decrease at $0.5 \mathrm{M}-\mathrm{NaCl}, 68 \%$ at $1 \mathrm{M}$ and $93 \%$ at $1.5 \mathrm{M}$, compared to controls grown in the absence of $\mathrm{NaCl}$.

When the electrolyte $\mathbf{K C l}$, or the non electrolytes sucrose or sorbitol, were substituted for $\mathrm{NaCl}$ as osmotic agents, at similar osmolalities, a comparable reduction in growth parameters was observed. In contrast, replacing $\mathrm{NaCl}$ with glycerol, which freely permeates the cells, did not affect bacterial growth (data not shown).

\section{Role of glycine betaine and choline in the osmoregulation of $B$. ammoniagenes}

We examined the effects of glycine betaine and choline on the growth of $B$. ammoniagenes in minimal medium M63 with various types of osmotic solutes. The addition of glycine betaine or choline to media of high osmotic strength did not show any effect on either growth rate or yield (Fig. 1). This could have resulted from the absence of uptake systems for these osmoprotectants in $B$. ammoniagenes. We therefore investigated the transport characteristics of these compounds. Glycine betaine uptake was determined in cells grown in M63 medium with no added $\mathrm{NaCl}$ or $1 \mathrm{M}-\mathrm{NaCl}$. The rate of betaine uptake was directly correlated with the medium osmola-

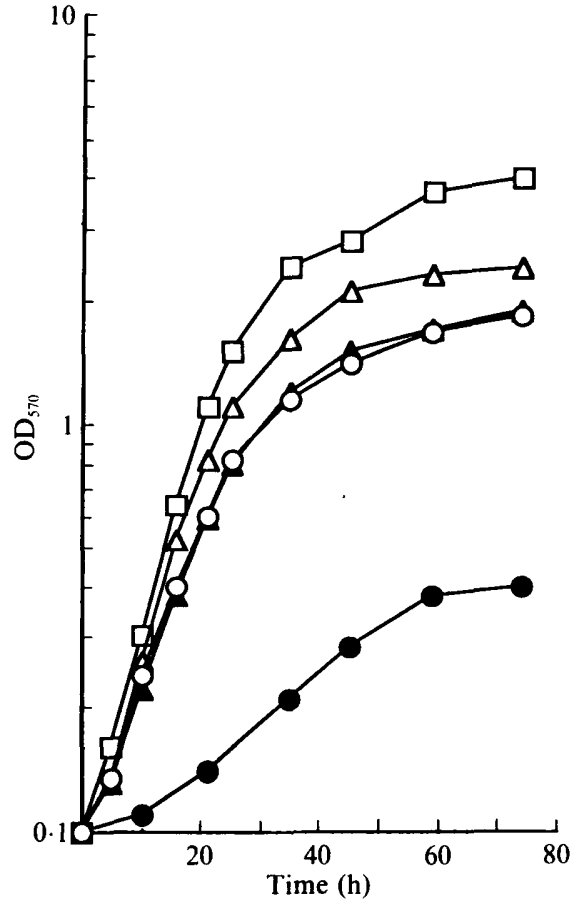

Fig. 1. Effect of $\mathrm{NaCl}$ concentration on growth of $B$. ammoniagenes. Cells were grown aerobically at $30^{\circ} \mathrm{C}$ in $\mathrm{M} 63$ medium. Symbols: $\square$, no added $\mathrm{NaCl} ; \triangle, 0.5 \mathrm{M}-\mathrm{NaCl} ; \triangle, 1 \mathrm{M}-\mathrm{NaCl} ; 0,1.5 \mathrm{M}-\mathrm{NaCl} ; 0,1 \mathrm{M}-$ $\mathrm{NaCl}$ with $1 \mathrm{~mm}$-glycine betaine.

lity, and increased from 1.5 to $9 \mathrm{nmol} \mathrm{m^{-1 }}$ (mg dry weight $)^{-1}$. Increasing medium osmolality to the same extent by $\mathrm{NaCl}, \mathrm{KCl}$ or sucrose resulted in a similar stimulation of betaine uptake, indicating that this stimulation was a consequence of increased osmolality rather than of increased salinity.

When cells were grown on media lacking $\mathrm{NaCl}$, and upshocked with $1 \mathrm{M}-\mathrm{NaCl}$ medium, we observed an immediate stimulation of betaine transport in nongrowing cells; the transport activity was identical to that of strains grown in $1 \mathrm{M}-\mathrm{NaCl}$ medium. If the cells were treated with chloramphenicol prior to upshock, no effect of the protein synthesis inhibitor was detected on betaine transport elicited by osmotic stress. From these data, we conclude that the betaine transport system is not induced by high osmotic pressure but is stimulated by elevated extracellular osmotic pressure.

The uptake of choline was also examined in cells grown with no added $\mathrm{NaCl}$ or $1 \mathrm{M}-\mathrm{NaCl}$ media. Choline uptake rate was very slow for cells grown at low osmolality and was only slightly increased when cells were grown in $1 \mathrm{M}-\mathrm{NaCl}$ medium.

We investigated whether $B$. ammoniagenes degraded choline and glycine betaine by cultivation in minimal medium with choline or glycine betaine as sole carbon or 
nitrogen source and $0,0.2$, and $0.5 \mathrm{M}-\mathrm{NaCl}$. No growth of $B$. ammoniagenes was observed after $4 \mathrm{~d}$ of incubation.

A radioactive labelling experiment was carried out to investigate the metabolic fate of these compounds. $B$. ammoniagenes was grown for $12 \mathrm{~h}$ with $\left[1,2-{ }^{14} \mathrm{C}\right]$ choline or glycine betaine in M63, in the absence and presence of $1 \mathrm{M}-\mathrm{NaCl}$. Glucose was used as carbon source. The cells were then extracted with alcohol to release their soluble components. For glycine betaine, 94 and $96 \%$ of the incorporated radioactivity was recovered in the soluble fraction for cells grown with 0 and $1 \mathrm{M}-\mathrm{NaCl}$, respectively. When the soluble fractions were analysed by chromatographic and electrophoretic techniques, all the radiocarbon was associated with glycine betaine.

When $\left[{ }^{14} \mathrm{C}\right]$ choline was incorporated into the medium, only a small fraction of the supplied radiocarbon was taken up by the cell at low osmolality, while up to $95 \%$ was absorbed at high osmolality. The soluble fraction contained most of the incorporated radiolabel; 97 and $91 \%$, for cells grown at low and high osmolality, respectively. After chromatographic and electrophoretic analysis of the soluble fraction, all the radioactivity was again localized in the glycine betaine spot.

To investigate the possibility of catabolic inhibition of choline and glycine degradation by glucose, the same experiments were repeated using lactate as carbon source. No difference was observed in the results; in all cases, labelled molecules were incorporated intracellularly and recovered in the soluble fraction as glycine betaine. We conclude that $B$. ammoniagenes could take up glycine betaine from the growth medium. Choline was transported slowly and readily transformed into glycine betaine. B. ammoniagenes is therefore similar to many species of bacteria which possess a choline oxidase but are unable to catabolize glycine betaine.

\section{Identification of endogenous accumulated solutes}

Since an appreciable growth rate was still observed at quite high osmolality, one might expect the synthesis and accumulation of other endogenous solute(s) to balance the high external osmotic pressure. Chromatographic and electrophoretic analyses were undertaken from ethanol-soluble fractions of cells grown on low or elevated osmotic strength media. Neither proline nor onium compounds, generally associated with osmotic stress, could be detected on chromatograms sprayed either with ninhydrin or Dragendorff reagents. However one spot appeared constantly after ninhydrin spraying and was highly dependent on the level of salt addition. Its $R_{F}$ value on chromatograms developed with $n$-butanol/ acetic acid/water $(12: 3: 5$, by vol.) was 0.52 , and in the aqueous phenol/ethanol system $(1: 1, \mathrm{v} / \mathrm{v})$, was 0.75 . The distance of migration in an electric field $(30 \mathrm{~V} \mathrm{~cm}-1)$, relative to that of choline, was $R_{c}=0.39$. The corresponding spot gave a blue-purple colour with ninhydrin reagent, which exhibited a red fluorescence when exposed to $280 \mathrm{~nm}$ UV light. The spot size and coloration intensity was directly correlated with salt concentration in the culture media up to $1 \mathrm{M}$. Above this concentration, no reproducible data were obtained.

The corresponding solute, suspected to be an amino acid due to its behaviour in an electric field and its reaction with ninhydrin, was isolated by preparative paper chromatography with phenol/ethanol as solvent and subjected to further purification using paper electrophoresis. ${ }^{13} \mathrm{C}$ and ${ }^{1} \mathrm{H}$ NMR spectroscopic and mass spectrometric analyses were carried out for structural determination.

The following chemical shifts were recorded for ${ }^{1} \mathrm{H}$ (300 MHz, $\delta$ p.p.m./DSS): $3.57(m, 1 \mathrm{H}) ; 3.35(m, 1 \mathrm{H})$; $2.93(t, 1 \mathrm{H}) ; 2.16(m, 1 \mathrm{H}) ; 1.79(m, 2 \mathrm{H}) ; 1.55(m, 3 \mathrm{H})$ and for ${ }^{13} \mathrm{C}(74.5 \mathrm{MHz}): 23.9\left(\mathrm{C}_{4}, \mathrm{C}_{5}\right) ; 28.2\left(\mathrm{C}_{3}\right) ; 46.5\left(\mathrm{C}_{6}\right)$; $59 \cdot 2\left(C_{2}\right) ; 174 \cdot 1(C=O)$. All these data were identical to those obtained from commercially available pipecolic acid.

In the mass spectrum, the molecular peak $\mathrm{M}^{\dagger}$ was at $m / z=129$, corresponding to $\mathrm{C}_{6} \mathrm{H}_{11} \mathrm{NO}_{2}$; the base peak $\mathrm{M} t-\mathrm{CO}_{2} \mathrm{H}=84$, was significant; calculated mass $=$ 129.078; found $=129.079$.

These data indicated the isolated compound to be pipecolic acid. Comparative co-chromatography with an authentic sample confirmed our predictions.

\section{Effect of osmotic strength on the accumulation of pipecolic acid}

Pipecolic acid content was determined using an HPLC technique. Data presented in Table 1 show that the content increased with medium osmolality from 40.3 in a two-fold diluted M63 medium to $130.8 \mathrm{nmol}$ (g dry weight) ${ }^{-1}$ in a medium containing $1 \mathrm{M}-\mathrm{NaCl}$. The addition of $1 \mathrm{~mm}$-glycine betaine to the culture medium did not affect the content of pipecolic acid in the absence

Table 1. Effect of increasing osmolality on the accumulation of intracellular pipecolic acid in B. ammoniagenes.

Values are means of duplicate determinations

\begin{tabular}{|c|c|}
\hline $\begin{array}{l}\text { Media } \\
{[\mathrm{NaCl}]}\end{array}$ & $\begin{array}{c}\text { Pipecolic acid } \\
{\left.\text { [nmol (mg dry weight })^{-1}\right]}\end{array}$ \\
\hline diluted $0 \mathrm{M}^{*}$ & $40 \cdot 3$ \\
\hline $0 \mathrm{M}$ & $42 \cdot 4$ \\
\hline $0.5 \mathrm{M}$ & $75 \cdot 3$ \\
\hline $0.8 \mathrm{M}$ & $109 \cdot 2$ \\
\hline $1.0 \mathrm{M}$ & 130.8 \\
\hline $0 \mathrm{M}+$ glycine betaine & 43.4 \\
\hline $1 \mathrm{M}+$ glycine betaine & $32 \cdot 0$ \\
\hline
\end{tabular}

* Minimal medium without added $\mathrm{NaCl}$, diluted twice with $\mathrm{H}_{2} \mathrm{O}$. 
Table 2. Incorporation of ${ }^{14} \mathrm{C}$ from lysine into pipecolic acid and the insoluble fraction $(E I F)$

Results are expressed as percent of total incorporated $\left[{ }^{14} \mathrm{C}\right] l y s i n e$. The $100 \%$ value is $10.6 \mathrm{MBq}$ ( $\mathrm{g}$ dry weight) ${ }^{-1}$ which remained constant independent of medium osmolality; non-metabolized ${ }^{14} \mathrm{C}$-lysine and minor labelled compounds constitute the rest of the radioactivity. Values are means of duplicate determinations.

\begin{tabular}{ccc}
\hline $\begin{array}{c}\text { Media } \\
{[\mathrm{NaCl}]}\end{array}$ & $\begin{array}{c}\text { Pipecolic acid } \\
(\%)\end{array}$ & $\begin{array}{r}\text { EIF } \\
(\%)\end{array}$ \\
\hline $0 \mathrm{M}$ & 28.3 & 41.2 \\
$0.5 \mathrm{M}$ & 52.9 & 23.1 \\
$1.0 \mathrm{M}$ & 64.6 & 14.2 \\
$1.5 \mathrm{M}$ & 72.8 & 4.2 \\
$2.0 \mathrm{M}$ & 51.8 & 2.0 \\
$1.0 \mathrm{M}+$ glycine betaine & 43.9 & 31.3 \\
\hline \hline
\end{tabular}

of $\mathrm{NaCl}$, but lowered the content to $32 \mathrm{nmol}(\mathrm{mg} \mathrm{DW})^{-1}$ in $1 \mathrm{M}-\mathrm{NaCl}$ medium (Table 1 ).

In order to determine whether pipecolic acid accumulation was the result of salt or osmotic stress, we determined the quantities accumulated when added $\mathrm{NaCl}(0.5$ and $1 \mathrm{M})$ was replaced by other solutes at identical osmolalities: $\mathrm{KCl}(0.5$ and $1 \mathrm{M})$, sucrose $(0.6$ and $1.1 \mathrm{M})$, sorbitol $(0.92$ and $1.8 \mathrm{M})$ and glycerol $(0.8$ and $1.5 \mathrm{M}) . \mathrm{KCl}$, sucrose and sorbitol exerted approximately the same effect as $\mathrm{NaCl}$, whereas glycerol had no effect on intracellular pipecolic acid content.

\section{Effect of increased osmolalities on ${ }^{14} C$-pipecolic acid biosynthesis}

Lysine is generally considered the main precursor of pipecolic acid (Stewart \& Larher, 1980). Cells of $B$. ammoniagenes fed with ${ }^{14} \mathrm{C}$-lysine incorporated radioactivity at a rate independent of medium osmolality. Both soluble (ESF) and insoluble (EIF) fractions were labelled. Moreover, substantial radioactivity was measured in carbon dioxide, mainly from the cells grown under the lowest salt concentration. Data given in Table 2 show that the labelling of the insoluble fraction (due to lysine incorporation into proteins) decreases sharply from $41.2 \%$ of the total radioactivity in the absence of $\mathrm{NaCl}$ to only $2 \%$ at $2 \mathrm{M}-\mathrm{NaCl}$. In contrast, the radioactivity in the corresponding soluble fraction increased considerably to $98.4 \%$ of the supplied ${ }^{14} \mathrm{C}$. Only two major radioactive compounds were detected in the soluble fraction: the non-metabolized lysine and pipecolic acid. One of the minor unidentified labelled compounds could correspond to $\alpha$-aminoadipic acid, a product of lysine oxidation reported in animal cells (Vianey-Liaud et al., 1991; Mihalik et al., 1991). Pipecolic acid accounted for the majority of the metabolized ${ }^{14} \mathrm{C}$-lysine (more than $70 \%$ of the total at
$1.5 \mathrm{M}-\mathrm{NaCl}$ ). No labelled cadaverine, the decarboxylation product of lysine, was detected on chromatograms.

When glycine betaine was added to the reaction mixture, incorporation of ${ }^{14} \mathrm{C}$ into pipecolic acid was markedly inhibited while incorporation into protein was stimulated (Table 2).

\section{Discussion}

This study presents evidence that $B$. ammoniagenes, when exposed to increasing medium osmolality, is capable of growth at relatively high external osmotic pressures and hence is able to perform intracellular osmotic adjustment. In B. ammoniagenes, glycine betaine transport and its accumulation were stimulated in media of high osmolality. This accumulation may result from the direct uptake of glycine betaine or from its synthesis from choline. In B. ammoniagenes, unlike B. lactofermentum (Kawahara et al., 1990) and most non-halophilic bacteria (Csonka, 1989), glycine betaine apparently does not stimulate growth rate in media of inhibitory osmotic strength. The absence of any apparent osmoprotective effect of choline and glycine betaine has also been described for another corynebacterium, Arthrobacter pascens (Rozwadowski et al., 1991). In this case, choline and glycine betaine appear to have no osmolyte function but are used as carbon sources. This is not the case in $B$. ammoniagenes, since glycine betaine is not metabolized either in low- or high-osmotic-strength media. Glycine betaine uptake activity appears to be regulated by activation of the betaine carrier; such results have been already reported for betaine uptake in another Grampositive bacterium (Lactobacillus acidophilus) by Hutkins et al. (1987) and is part of the betaine uptake system in enterobacteria (Csonka, 1989). By analogy to the models proposed for $\mathrm{K}^{+}$and carbohydrate transport systems in E. coli (Epstein, 1986; Roth et al., 1985) the deformation of cell membranes caused by a change in turgor alters the conformation of the membrane embedded carrier proteins, stimulating the inward transport of betaine.

$B$. lactofermentum grown in high osmotic strength media accumulates proline. Glycine betaine added to the growth media is taken up rapidly and accumulated into the cell in preference to proline (Kawahara et al., 1990). A similar phenomenon occurs in $B$. ammoniagenes; in this bacterium, glycine betaine tends to repress pipecolic acid synthesis, and perhaps accumulation of other unidentified compounds. Thus, in spite of its apparent inefficiency on growth stimulation, glycine betaine must be considered an osmoprotective compound for $B$. ammoniagenes.

The non-proteic pipecolic acid accumulated as a response to osmotic constraint in $B$. ammoniagenes 
(Table 1). It is the first time that this phenomenon has been reported in bacteria, as far as we are aware. Intracellular pipecolic acid content was closely related to elevation of external osmotic pressure, independent of the solute used as long as this solute was not penetrant. The permeant solute glycerol did not trigger any imino acid accumulation; this may indicate that loss of cell turgor, rather than increasing medium osmolality, was the mechanism leading to solute accumulation. Pipecolic acid did not accumulate when the culture medium was supplemented with glycine betaine, suggesting that this potent osmoprotectant could efficiently replace the endogenously accumulated imino acid. Similar results had been reported for other micro-organisms, and it is generally accepted that stressed cells prefer to take up osmoprotectant rather than synthesize endogenous osmolyte, which is energetically expensive (Whatmore et al., 1990; Herzog et al., 1990; Strøm et al., 1986).

With the exception of several reports on lysine metabolism in Pseudomonas putida (Basso et al., 1962; Miller \& Rodwell, 1971; Perfetti et al., 1972) little is known concerning the occurrence and metabolism of pipecolic acid in bacteria. In plants, a few studies have reported the occurrence of pipecolic acid together with proline in response to osmotic stress (Goas et al., 1976; Stewart \& Larher, 1980), but it is unclear why bacteria should accumulate this unusual solute. Should it be considered as a stress signal or rather as a genuine osmoprotectant? Indeed, the maximum pipecolic acid content $\left[130 \mathrm{nmol}\left(\mathrm{g} \mathrm{DW}^{-1}\right]\right.$ at a salinity of $1 \mathrm{M}$ is markedly lower than values reported from other organisms at similar salinities, e.g. $260 \mathrm{nmol}$ of the cyclic amino acid ectoine in Halomonas elongata (Wohlfarth et al., 1990) or $300 \mathrm{nmol}$ of proline in B. lactofermentum (Kawahara et al., 1989). Moreover since the natural abundance ${ }^{13} \mathrm{C}$ NMR analysis of a raw ethanol extract does not exhibit any significant signal for pipecolic acid (data not shown), this imino acid might not be considered to be the major osmoprotectant in $B$. ammoniagenes.

The accumulation of pipecolic acid is a further example of the remarkable similarities between bacteria and plants in their response to osmotic stress, and suggests that there may be close parallels in the mechanisms they employ to relieve it.

Experiments using ${ }^{14} \mathrm{C}$-lysine show that this amino acid is the probable precursor of pipecolic acid in $B$. ammoniagenes. The rate of this metabolic step was osmolality-dependent and severly inhibited in the presence of exogenously-supplied osmoprotectant betaine. At low osmolality, pipecolic acid can be metabolized, giving $\alpha$-aminoadipic acid.

The data presented in this paper imply that pipecolic acid may play an osmotic role in $B$. ammoniagenes, but futher investigations are now needed to establish the metabolic pathways and the mechanisms involved in the regulation of pipecolic acid synthesis.

We wish to thank Dr S. Himdi-Kabbab for expert technical assistance in chemical structure determination by spectroscopic methods.

\section{References}

BAsso, L. V., RAO, D. R. \& RodWELL, V. W. (1962). Metabolism of pipecolic acid in a Pseudomonas species. II $\Delta^{1}$-piperideine-6carboxylic acid and $\alpha$-amino adipic acid- $\delta$-semialdehyde. Journal of Biological Chemistry 237, 2239-2245.

Bernard, T., Pocard, J. A., Perroud, B. \& Le Rudulier D. (1986). Variations in the response of salt-stressed Rhizobium strains to betaines. Archives of Microbiology 143, 359-364.

BOTSFORD, J. L. (1984). Osmoregulation in Rhizobium meliloti: inhibition of growth by salts. Archives of Microbiology 137, 124-127.

Brown, A. D. (1976). Microbial water stress. Bacteriological Reviews 40, 803-846.

Chang, Y. Y., KNetch, R. \& Braun, D. G. (1983). Amino acid analysis in the picomole range by precolumn derivatization and high performance liquid chromatography. Methods in Enzymology 91, 4148.

Christian, J. H. B. (1955). The influence of nutrition on the water relations of Salmonella oranienburg. Australian Journal of Biological Science 8, 75-82.

Christian, J. H. B. \& Waltho, J. (1961). The sodium and potassium content of non-halophilic bacteria in relation to salt tolerance. Journal of General Microbiology 25, 97-102.

CsonkA, L. N. (1989). Physiological and genetic responses of bacteria to osmotic stress. Microbiological Reviews 53, 121-147.

DUNLAP, V. J. \& CSONKA, L. N. (1985). Osmotic regulation of L-proline transport in Salmonella typhimurium. Journal of Bacteriology 163, 296-304.

EPSTEIN, W. (1986). Osmoregulation by potassium transport in Escherichia coli. FEMS Microbiology Letters 39, 73-78.

Goas, M., Goas, G. \& LaRHER, F. (1976). Formation de l'acide pipécolique chez Triglochin maritima. Canadian Journal of Botany 54, 1221-1227.

Herzog, M., Galinski, E. A. \& TRÜPER, H. G. (1990). Degradation of the compatible solute trehalose in Ectothiorhodospira halochloris: isolation and characterization of trehalase. Archives of Microbiology 153, 600-606.

Hua, S. S. T., Tsai, V. Y., Lichens, G. M. \& Noma, A. T. (1982). Accumulation of amino acids in Rhizobium sp. strain WR 1001 in response to sodium chloride salinity. Applied and Environmental Microbiology 44, 135-140.

Hutkins, R. W., Ellefson, W. L. \& Kashiket, E. R. (1987). Betaine transport imparts osmotolerance on a strain of Lactobacillus acidophilus. Applied and Environmental Microbiology 53, 2275-2281.

IkUta, S., MatuUra, K., Imamura, S., Misaki, H. \& HoriUti, Y. (1977). Oxidative pathway of choline to betaine in the soluble fraction prepared from Arthrobacter globiformis. Journal of Biochemistry 82, 157-163.

IMHOFF, J. F. (1986). Osmoregulation and compatible solutes in eubacteria. FEMS Microbiology Reviews 39, 57-66.

Kawahara, Y., Ohsumi, T., Yoshihara, Y. \& Ikeda, S. (1989). Proline in the osmoregulation of Brevibacterium lactofermentum. Agricultural and Biological Chemistry 53, 2475-2479.

Kawahara, Y., Yoshimara, Y., IKeda, S. \& Hirose, Y. (1990). Effect of glycine betaine, an osmoprotective compound on the growth of Brevibacterium lactofermentum. Applied Microbiology and Biotechno$\log y$ 33, 574-577.

КосH, A. L. (1984). Shrinkage of growing Escherichia coli cells by osmotic stress. Journal of Bacteriology 159, 919-924. 
Le RUdULIER, D. \& BERNARD, T. (1986). Salt tolerance in Rhizobium: a possible role for betaines. FEMS Microbiology Reviews 39, 67-72.

MAKEMsSON, J. C. \& HASTINGS, J. W. (1979). Glutamate functions in osmoregulation in a marine bacterium. Applied and Environmental Microbiology 38, 178-180.

MEASURES, J. C. (1975). Role of amino acids in osmoregulation of nonhalophilic bacteria. Nature, London 257, 398-400.

Mihalix, S. J., McGuiness, M. \& Watxins, P. A. (1991). Purification and characterization of peroxisomal L-pipecolic acid oxidase from monkey liver. Journal of Biological Chemistry 266, 4822-4830.

MILLER, D. L. \& RODWELL, V. W. (1971). Metabolism of basic amino acids by Pseudomonas putida. Properties of the inducible lysine transport system. Journal of Biological Chemistry 246, 1765-1771.

Miller, J. (1972). Experiments in Molecular Genetics. Cold Spring Harbor, NY: Cold Spring Harbor Laboratory.

Perfetti, R., Campiell, R., Titus, J. \& Hartuine, R. A. (1972). Catabolism of pipecolate to glutamate in Pseudomonas putida. Journal of Biological Chemistry 247, 4089-4095.

PerRoud, B. \& Le RUdULIER, D. (1985). Glycine betaine transport in Escherichia coli: osmotic modulation. Journal of Bacteriology 161, 393-401.

Roth, W. G., Porter, S. E., Leckie, M. P., Porter, B. E. \& DieTZLeR, D. N. (1985). Restoration of cell volume and the reversal of carbohydrate transport and growth inhibition of osmotically upshocked Escherichia coli. Biochemical and Biophysical Research Communications 126, 442-449.

Rozwadowski, K. L., Khachatourians, G. G. \& Selvara, J. G. (1991). Choline oxidase, a catabolic enzyme in Arthrobacter pascens, facilitates adaptation to osmotic stress in Escherichia coli. Journal of Bacteriology 173, 472-478.
Stewart, G. R. \& LARHER, F. (1980). Accumulation of amino acids and related compounds in relation to environmental stress. The Biochemistry of Plants 5, 609-635.

Strøm, A. R., FalkenberG, P. \& Landfald, B. (1986). Genetics of osmoregulation in Escherichia coli: uptake and biosynthesis of organic osmolytes. FEMS Microbiology Reviews 39, 79-86.

Tempest, D. W., MeERS, J. L. \& BRown, C. M. (1970). Influence of environment on the content and composition of microbial free amino acid pools. Journal of General Microbiology 64, 171-185.

Troll, W. \& Lindsley, J. (1955). A photometric method for the determination of proline. Journal of Biological Chemistry 215, 655660.

Vianey-liaud, C., Divry, P., Poinas, C. \& Mathieu, M. (1991). Le métabolisme de la lysine chez l'homme. Annales de Biologie Clinique 49, 18-26.

WhATMORE, A. M., ChudeK, J. A. \& ReEd, R. H. (1990). The effects of osmotic upshock on the intracellular solute pools of Bacillus subtilis. Journal of General Microbiology 136, 2527-2535.

Wohlfarth, A., SeVerin, J. \& Galinski, E. A. (1990). The spectrum of compatible solutes in heterotrophic halophilic eubacteria of the family Halomonadaceae. Journal of General Microbiology 136, 705712.

YanCey, P. H., Clark, M. E., Hand, S. C., Bowlus, R. D. \& Somero, G. N. (1982). Living with water stress: evolution of osmolyte systems. Science 217, 1214-1222.

YAP, S. F. \& LIM, S. T. (1983). Response of Rhizobium sp. UMKL 20 to sodium chloride stress. Archives of Microbiology 135, 224-228. 